\title{
PEMBUATAN STANDARD OPERATING PROCEDURE (SOP) LAYANAN DOMAIN DAN HOSTING MENGGUNAKAN METODE ANALISIS KESENJANGAN (STUDI KASUS: DPTSI ITS)
}

\author{
Ervina Chintia $^{\text {1), }}$, Hanim Maria Astuti ${ }^{2)}$, Febriliyan Samopa $^{3)}$, Sholiq $^{4)}$, dan Almira Filiazsanti ${ }^{5)}$ \\ 1,2,3,4,5 Departemen Sistem Informasi, Institut Teknologi Sepuluh Nopember \\ $1,2,3,4,5$ J1. Raya ITS, Keputih, Kec. Sukolilo, Surabaya, 60111 \\ E-mail : ervinachintia@gmail.com ${ }^{1)}$, hanim@is.its.ac.id ${ }^{2)}$, iyan@is.its.ac.id ${ }^{3)}$, sholiq@is.its.ac.id ${ }^{4)}$, \\ almira.filias@gmail.com ${ }^{5}$
}

\begin{abstract}
ABSTRAK
Direktorat Pengembangan Teknologi dan Sistem Informasi (DPTSI) merupakan direktorat yang bertugas menyediakan dan mengelola layanan SI/TI di ITS. Dalam mengelola layanan diperlukan tata kelola untuk memastikan layanan dapat diberikan dengan baik. Tata Kelola Organisasi diterapkan untuk meningkatkan kinerja, keunggulan kompetitif, dan pencapaian tujuan bisnis. Sehingga bila tata kelola jelas, hal tersebut akan mempermudah kinerja DPTSI dalam memberikan layanan. Saat ini, DPTSI masih memiliki berbagai permasalahan terkait prosedur layanan SI. Maka dari itu diperlukan sebuah pengembangan SOP dan pada penelitian ini akan dilakukan dengan menggunakan metode analisis kesenjangan (Gap Analysis), dengan hasil akhir berupa prosedur. Pengembangan SOP yang dilakukan berupa penyempurnaan SOP yang sudah ada namun tidak bisa secara maksimal digunakan karena isi kurang jelas. Dalam pembuatan SOP akan dilakukan pengamatan terhadap kondisi dari sisi organisasi (management perception) dengan kondisi yang diharapkan dari sisi pengguna (customer expectation) terhadap SOP untuk keseluruhan layanan SI/TI yang dimiliki oleh DPTSI. Metode Analisis Kesenjangan dipilih dengan mempertimbangkan kebutuhan pengguna bertujuan untuk dapat memberikan kepuasan kepada customer. Hasil pengamatan terhadap kedua kondisi tersebut, selanjutnya akan dilakukan analisis kesenjangan untuk mengetahui perbedaan antara kedua kondisi untuk selanjutnya akan digunakan sebagai bahan pertimbangan dalam pembuatan SOP layanan.
\end{abstract}

Kata Kunci: SOP, Analisis Kesenjangan, Tata Kelola Organisasi

\section{PENDAHULUAN}

Dalam dunia pendidikan keberadaan SI/TI merupakan salah satu komponen yang tidak dapat dipisahkan dari aktivitas pendidikan (Sudibyo, 2011). Bahkan kini, setiap instansi pendidikan memiliki sebuah organisasi atau unit yang mengelola SI/TI secara mandiri. Salah satunya yakni Institut Teknologi Sepuluh Nopember yang memiliki Direktorat Pengembangan Teknologi dan Sistem Informasi - DPTSI, sebagai unit khusus yang bertugas untuk melakukan pengelolaan dan pengembangan terhadap SI/TI di lingkungan ITS.

Tata kelola teknologi informasi dibutuhkan oleh institusi pendidikan tinggi tujuannya yaitu agar tercipta proses penyebaran ilmu dalam kegiatan pembelajaran yang lebih interaktif dan dinamis, transparansi tata kelola operasional kegiatan institusi, serta peningkatan kinerja berbasis evaluasi dengan penilaian yang transparan, serta keamanan data serta informasi yang berhubungan dengan hak intelektual seseorang (Albrecht and Pirani, 2004) (Bianchi and Sousa, 2016). Bentuk dari tata kelola bermacam-macam, diantaranya adalah kebijakan, prosedur, instruksi kerja, dan petunjuk pedoman kerja untuk membantu dalam pengelolaan layanan (Greene, 2014). Dan bentuk tata kelola yang akan dihasilkan dari penelitian ini adalah berupa prosedur, atau suatu dokumen prosedur operasi standar untuk seluruh layanan SI/TI di DPTSI ITS. Dan fokus studi kasus utama dari penelitian ini adalah sub direktorat Layanan Teknologi Sistem Informasi - LTSI, yang masih berada dibawah DPTSI ITS.

Standard Operating Procedure (SOP) merupakan serangkaian panduan yang terdokumentasi secara jelas, lengkap, dan rinci mengenai proses, tugas, dan peran setiap individu atau kelompok yang dilakukan sehari-hari di dalam suatu organisasi (Herdiyanti dkk., 2018; Rachmi dkk., 2014). SOP berupa dokumen/instrumen dari gambaran langkah-langkah kerja (sistem, mekanisme dan tata kerja internal) yang diperlukan dalam pelaksanaan suatu tugas untuk mencapai tujuan yang memuat tentang proses dan prosedur suatu kegiatan yang bersifat efektif dan efisien berdasarkan suatu kerangka kerja ter standar (Armoko, 2012). Dengan begitu, dengan adanya SOP maka dapat menjamin bahwa semua operator melakukan tugas dengan cara yang sama, dengan mengacu pada panduan yang ada sehingga mendapatkan hasil yang diharapkan dari proses.

Pada kenyataannya dalam menjalankan tugas memberikan layanan, LTSI memiliki beberapa 
permasalahan SOP yang telah ada, terutama untuk layanan domain, web hosting, VPS, dan colocation server permasalahan yang ditemukan diantaranya, SOP yang ada membingungkan operator dalam melakukan operasi layanan, dan terdapat kesenjangan antara kondisi prosedur yang ada dari sisi organisasi dan dari sisi keinginan yang diharapkan pengguna sehingga antara operator dan pengguna memiliki perspektifnya masingmasing yang berbeda terhadap layanan.

Berdasarkan permasalahan itu, muncul indikasi kebutuhan untuk melakukan perbaikan terhadap SOP layanan domain dan hosting yang telah ada agar SOP dapat digunakan sebagai panduan operasional layanan dengan menggunakan analisis kesenjangan antara harapan customer dan persepsi manajemen.

Oleh karena itu, pada penelitian ini akan dibuat sebuah dokumen SOP mengenai layanan domain, web hosting, VPS, dan Colocation Server pada subdirektorat LTSI. Dalam pembuatannya akan dilakukan analisis kesenjangan (gap analysis) untuk mengetahui kesenjangan antara kondisi dari sisi organisasi (management perception) dengan kondisi yang diharapkan dari sisi pengguna (customer expectation). Kesenjangan adalah perbedaan antara kondisi ideal dengan kondisi yang sebenarnya terjadi. Kesenjangan diamati dengan melihat terhadap kondisi SOP yang ada, baik dari sisi organisasi dengan melihat SOP layanan yang sudah dimiliki dan melihat apa yang menjadi harapan dari sisi pengguna terhadap SOP layanan yang dimiliki dengan mempertimbangkan bentuk SOP yang baik. Dokumen SOP yang dihasilkan ini, diharapkan dapat dijadikan sebagai acuan atau pedoman yang terstruktur oleh DPTSI dalam memberikan layanan dengan baik.

\section{RUANG LINGKUP}

Adapun permasalahan yang diselesaikan dalam penelitian ini yakni bagaimana membuat dokumen SOP yang dapat mewakili DPTSI sebagai penyedia layanan TI dan user yakni civitas ITS sebagai pengguna layanan TI. Penelitian ini memiliki batasan yakni SOP yang dihasilkan hanya mencakup domain Layanan Domain dan Hosting. Hasil dari penelitian ini akan digunakan sebagai dokumen acuan bagi penyedia layanan TI dan pengguna layanan TI dalam keseharian provisi layanan Domain dan Hosting di ITS.

\section{BAHAN DAN METODE}

Bab ini berisikan beberapa kajian teoretis yang dibutuhkan untuk penelitian.

\subsection{Tata Kelola Teknologi Informasi}

Teknologi Informasi adalah suatu bagian yang penting dari sebagian besar organisasi yang ada saat ini dan akan menjadi hal kritis di masa mendatang. Oleh karena itu, Tata Kelola TI harus menjadi bagian utuh dari Tata Kelola Organisasi dan diterapkan untuk meningkatkan kinerja, keunggulan kompetitif, dan mencapai tujuan bisnis. Tata Kelola TI merupakan keputusan yang paten dan dalam bingkai yang bisa dipertanggung jawabkan untuk mendorong keinginan dan kebiasaan penggunaan Teknologi Informasi (Henderi and Sunarya, 2008). Tata Kelola Teknologi Informasi juga dapat diartikan sebagai kegiatan untuk mengelola penggunaan TI agar menghasilkan keluaran yang maksimal dalam organisasi, membantu proses pengambilan keputusan dan membantu proses pemecahan masalah. Tata kelola TI merupakan tanggung jawab dewan direksi dan manajemen eksekutif dan juga merupakan bagian yang terintegrasi yang menjadi bagian dari tata kelola perusahaan (De Haes and Van Grembergen, 2015).

\subsection{Penyedia Layanan TI}

Penyedia layanan TI atau IT Service Provider adalah sebuah organisasi atau perusahaan atau unit yang menyediakan layanan Teknologi Informasi untuk pelanggan.

\subsection{Pengguna Layanan TI}

Dalam konteks layanan TI, tentunya terdapat istilah user dan customer. Namun dalam hal ini customer dibedakan dari user, karena tidak semua customer menggunakan secara langsung layanan TI (tidak semua customer adalah user), dan user tidak memiliki autoritas penuh terhadap layanan TI seperti halnya customer sebagai pihak pembeli layanan TI. Untuk lebih jelasnya, customer dalam hal ini adalah yang memakai, membeli layanan TI sedangkan user adalah staf-staf perusahaan yang bertugas sebagai operator sistem layanan TI (Susanto, 2016). Ada 2 kategori customer yaitu:

1. Internal Customer

2. Eksternal Customer

\subsection{Analisis Kesenjangan (Gap Analysis)}

Gap Model adalah perbedaan antara kondisi aktual dengan kondisi ideal (Hermana, 2015). Sedangkan analisis kesenjangan merupakan aktivitas membandingkan antara kondisi aktual dan kondisi ideal untuk membantu dalam memahami kualitas layanan suatu organisasi. Pada aktivitas ini dapat dijadikan sebagai evaluasi bisnis untuk mengurangi kesenjangan agar tercapainya kondisi yang ideal. Di lingkungan TI, analisis kesenjangan dapat menentukan investasi TI yang efektif dan efisien bagi proses bisnis organisasi. Analisis kesenjangan di dalam bidang TI digambarkan menjadi 2 poin, yaitu:

1. AS-IS, menggambarkan posisi dimana saat ini berada.

2. TO-BE, menggambarkan keinginan yang ingin dituju.

Dua poin yang ada TO-BE dan AS-IS dianalisis apakah gap diantara dua poin tersebut cukup jauh atau dekat (Ali, 2013). Ada 5 macam Gap Model. Satu gap adalah kesenjangan dari sisi pelanggan dan keempat lainnya adalah dari sisi kesenjangan penyedia. Berikut 
ini adalah gambaran dari kelima gap tersebut yang ditunjukkan pada gambar 1 .

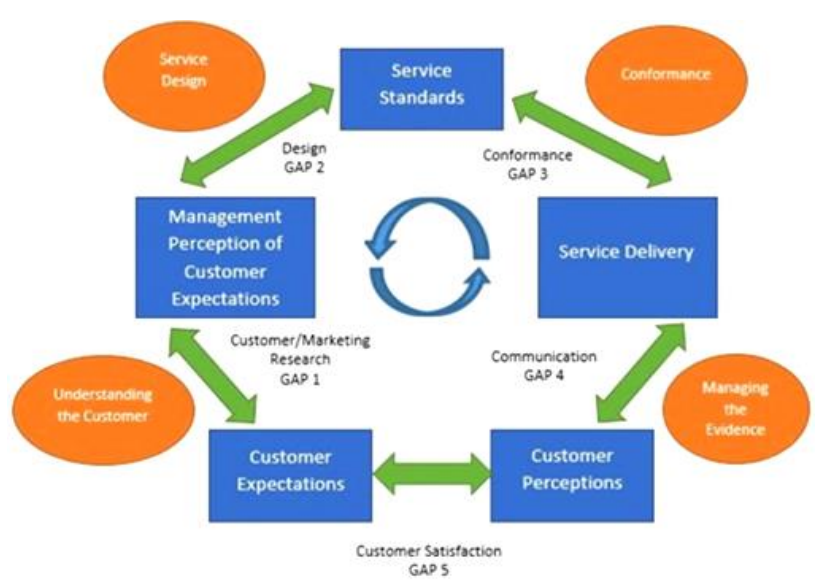

Gambar 1. Gap Model menurut Boundless

Model kesenjangan yang digunakan dalam penelitian ini adalah model kesenjangan gap 1 (Knowledge Gap) yang merupakan gap antara harapan pelanggan dan persepsi manajemen, dimana pihak manajemen memersepsikan ekspektasi pelanggan terhadap kualitas layanan tidak akurat. Beberapa kemungkinan penyebabnya antara lain: informasi yang didapatkan dari riset pasar dan analisis permintaan kurang akurat atau tidak adanya aliran informasi yang jelas antara staf ke pihak manajemen.

Langkah-langkah untuk melakukan analisis ini, yaitu current state yang merupakan aktivitas pada saat ini yang dilakukan yang menggambarkan kondisi terkini dari aktivitas yang dilakukan, kemudian expectation yang berarti gambaran yang ingin dicapai oleh organisasi di masa yang akan datang, di lanjut dengan gap yang merupakan gambaran kesenjangan yang terjadi antara kondisi saat ini dengan kondisi di masa yang akan datang, berikutnya adalah langkah problem yang menjelaskan gambaran permasalahan yang terjadi akibat kesenjangan yang terjadi, dan terakhir adalah recommendations yang merupakan solusi yang mungkin dapat dilakukan sebagai upaya untuk mengurangi atau menghilangkan kesenjangan yang telah. Gambaran langkah-langkah dari proses analisis kesenjangan secara umum dapat dilihat pada gambar 2.

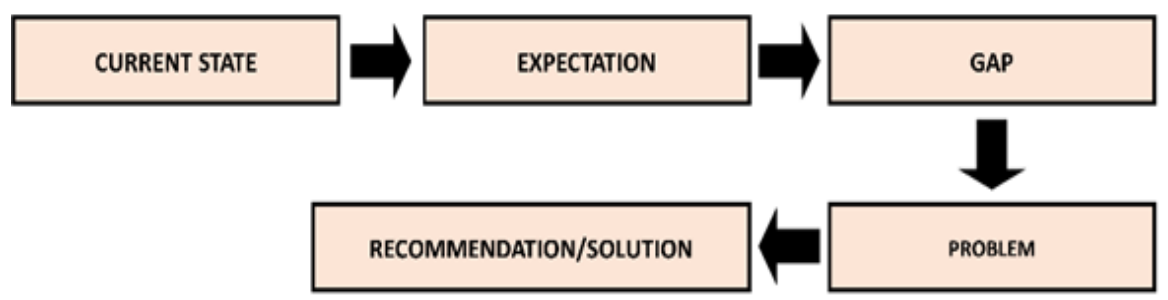

Gambar 2. Langkah Analisis Kesenjangan

\subsection{SOP (Standard Operating Procedure)}

SOP memiliki tujuan untuk mencapai operasi dengan benar dan selalu dengan cara yang sama. SOP dapat menandakan persetujuan dengan kebutuhan organisasi dan pemerintah dan dapat digunakan sebagai bagian dari program pelatihan personil, karena harus memberikan instruksi kerja yang terperinci. Terdapat tujuh kriteria SOP yang baik sesuai dengan aturan PERMENPEN, antara lain harus specific (harus spesifik dan jelas), complete (lengkap, tidak ada kekurangan), under stable (mudah dipahami), applicable (dapat diterapkan), controllable (dapat dikontrol dan mampu mengontrol), auditable (dapat diaudit kembali apabila terjadi permasalahan), dan changeable (dapat diubah sesuai dengan kebutuhan) (Akyar, 2012). Format umum SOP yang dapat digunakan, antara lain:

1. Langkah Sederhana (Simple Steps)

2. Tahapan Berurutan (Hierarchical Steps)

3. Grafik(Graphic)

4. Diagram Alir(Flowcharts)

Dokumen SOP Aparatur Negara yang pada hakikatnya merupakan dokumen berisi prosedurprosedur yang distandarkan dan secara keseluruhan membentuk satu kesatuan proses, sehingga informasi yang dimuat dalam dokumen SOP meliputi: Unsur Dokumentasi dan Unsur Prosedur. Unsur Dokumentasi terdiri dari 4 bagian, yaitu halaman judul, halaman pengesahan, daftar isi, dan penjelasan singkat penggunaan. Sedangkan pada unsur Prosedur terdiri dari 
2 bagian yaitu bagian identitas dan bagian flowchart. SOP yang telah dirumuskan oleh tim harus melalui tahapan pengujian yang dilakukan melalui penerapan langsung pada unit pengguna atau pelaksana prosedur. Proses pengujian bertujuan untuk mendapatkan informasi lebih lanjut yang belum ditampung dalam prosedur atau yang diperlukan oleh tim sebagai bentuk peninjauan atas SOP, sehingga SOP yang dihasilkan dapat memenuhi kebutuhan organisasi dan customer sebagai pengguna layanan.

\subsection{Tahapan Penelitian}

Metodologi penelitian merupakan acuan dalam melakukan penelitian sehingga alur penelitian dapat terstruktur. Berikut metodologi penelitian ditampilkan pada di bawah ini. Alur pengerjaan penelitian dengan menggunakan model konseptual bertujuan untuk memberikan rancangan terstruktur tentang konsep relevan dalam pengerjaan penelitian. Gambar 3 merupakan bagan metodologi penelitian.

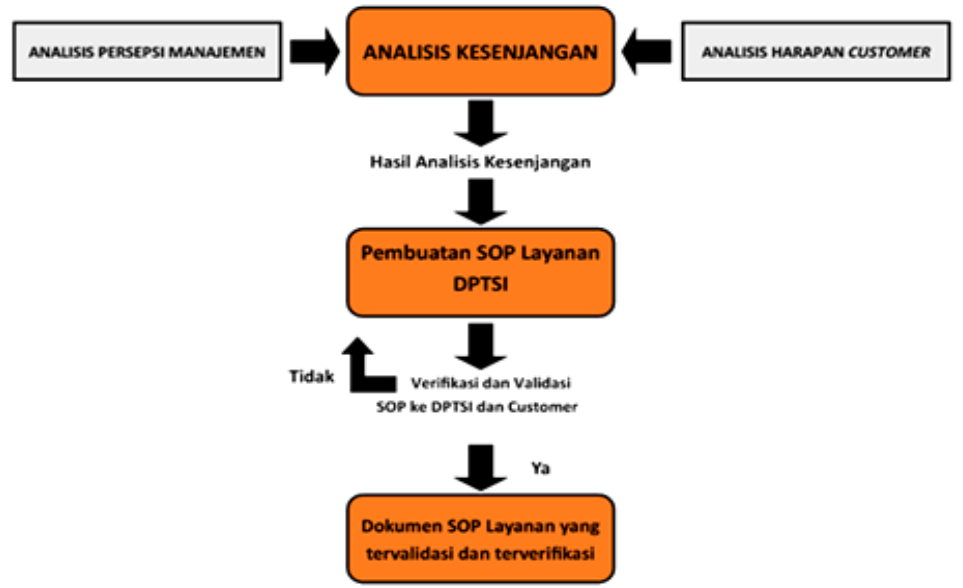

Gambar 3. Bagan Metodologi Penelitian

\section{Tahapan Persiapan}

Tahapan pertama penelitian adalah tahap persiapan. Tahapan ini dilakukan untuk memahami kebutuhan yang akan digunakan untuk pembuatan dan pengembangan SOP. Namun sebelum melakukan aktivitas pada tahap persiapan, terlebih dahulu harus memahami latar belakang permasalahan penelitian.

\section{Tahap Penggalian Data dan Informasi}

Tujuan dari pengambilan data dan informasi mengenai kondisi kekinian manajemen layanan TI pada LTSI yaitu untuk mengetahui ketersediaan dokumen SOP yang ada di LTSI. Tahapan ini dilakukan dengan mengumpulkan semua data dan informasi terkait penelitian. Untuk melakukan pengambilan data untuk mengetahui kondisi existing manajemen dilakukan beberapa aktivitas, yaitu dengan melakukan wawancara, dan forum group discussion untuk mendapatkan data dan informasi mengenai kondisi kekinian atau persepsi manajemen terhadap SOP layanan. Sebagai masukan untuk analisis kesenjangan, maka data dan informasi yang ingin didapatkan untuk mengetahui persepsi manajemen mengacu pada prinsip pembuatan SOP sebagaimana yang telah diuraikan pada bab sebelumnya seperti kemudahan dan kejelasan, efisiensi dan efektivitas, keselarasan, keteraturan, dinamis, berorientasi pada pihak yang dilayani, kesesuaian dengan peraturan perundang-undangan, kepatuhan hukum dan kepastian hukum.

\section{Tahap Pembuatan SOP}

Kemudian hasil dari penggalian data dan informasi, maka selanjutnya adalah tahap pembuatan SOP. Pada tahap ini akan dihasilkan SOP sementara dengan menggunakan metode Gap Analysis. Dalam proses pembuatannya akan mempertimbangkan hasil dari analisis kesenjangan pada tahap sebelumnya yaitu gap antara kondisi existing SOP layanan yang ada di LTSI dengan harapan atau perspektif dari sisi customer layanan.

4. Tahap Verifikasi dan Validasi

Proses verifikasi SOP dilakukan untuk menguji kesesuaian dokumen SOP yang dibuat dengan kondisi yang ada di LTSI dan sesuai dengan kondisi customer. Dalam tahap ini SOP sementara akan disampaikan kepada pengguna dan manajemen guna memperoleh masukan dari pihak-pihak yang terlibat dalam prosedur. Serta juga akan dilakukan simulasi terhadap SOP sementara untuk melihat sejauh mana SOP yang telah dirumuskan akan dapat berjalan sesuai dengan kondisi senyatanya. Untuk selanjutnya akan dilakukan penyempurnaan rumusan SOP atas dasar hasil yang ditemukan pada saat simulasi. Pelaksanaan uji coba untuk melihat sampai sejauh mana tingkat kemudahan, kesesuaian dan ketepatan SOP dalam pelaksanaannya.

5. Tahap Akhir

Tahap akhir ini bertujuan untuk melakukan perumusan kesimpulan mengenai aktivitas pembuatan 
dokumen SOP terhadap layanan LTSI ITS dengan menggunakan analisis kesenjangan. Dokumen SOP yang telah ter validasi dan ter verifikasi akan digunakan sebagai bahan untuk menyusun kesimpulan dimana salah satu hasil kesimpulan yang diperoleh adalah dokumen SOP layanan LTSI dibutuhkan oleh pihak DPTSI dalam memberikan pelayanan dan supaya penyampaian layanan dapat tersampaikan dengan baik kepada customer maka perlu dilakukan analisis kesenjangan dengan memperhatikan dari sisi harapan customer.

\section{PEMBAHASAN}

Analisis kesenjangan adalah aktivitas membandingkan antara kondisi proses bisnis saat ini dengan kondisi di masa yang akan datang terkait SOP Layanan Domain dan Hosting yang telah ada. Pada bagian pendahuluan telah dijelaskan bahwa perlu dilakukan perbaikan terhadap dokumen SOP tersebut, agar LTSI dapat menyediakan layanan sesuai dengan kebutuhan pelanggan secara baik. Salah satu perbaikan yang dilakukan adalah dengan melakukan analisis terhadap bentuk SOP yang sudah ada berdasarkan hasil kesenjangan antara kondisi persepsi manajemen dengan kondisi harapan customer terkait kondisi existing SOP layanan domain dan hosting. Pada tahap analisis kesenjangan ini dimulai dengan memetakan kondisi persepsi manajemen saat ini dengan kondisi harapan customer, untuk selanjutnya dicari kesenjangan antara keduanya.

\subsection{Analisis Current State dan Expectations}

Analisis ini dilakukan untuk mengetahui bentuk SOP seperti apa yang baik dan mudah untuk digunakan. Aspek pembanding yang digunakan ada 6 yaitu: aspek bentuk SOP, aspek penulisan di dalam alur proses, aspek visualisasi alur, isi SOP, formatting dokumen SOP, dan tingkat ke rincian. Hasil dari analisis kesenjangan ini berupa solusi-solusi sebagai masukan dalam melakukan perbaikan SOP yang didasarkan pada hasil kesenjangan antara harapan customer dengan persepsi manajemen pada tiap-tiap aspek yang ditunjukkan pada tabel 1 .

Tabel 1. Hasil Analisis Kesenjangan

\begin{tabular}{|c|c|c|}
\hline $\begin{array}{c}\text { Kode } \\
\text { Aspek }\end{array}$ & Aspek & $\begin{array}{c}\text { Kesenjangan antara } \\
\text { Manajemen dan } \text { Customer }\end{array}$ \\
\hline P01 & Bentuk SOP & Tidak terjadi kesenjangan. \\
\hline P02 & $\begin{array}{c}\text { Penulisan pada } \\
\text { Alur Proses }\end{array}$ & Terjadi kesenjangan \\
\hline P03 & Visualisasi Alur & Terjadi Kesenjangan \\
\hline P04 & Isi SOP & Tidak Terjadi Kesenjangan \\
\hline P05 & $\begin{array}{c}\text { Formatting } \\
\text { Dokumen }\end{array}$ & Tidak Terjadi Kesenjangan \\
\hline P06 & $\begin{array}{c}\text { Tingkat Ke } \\
\text { rincian }\end{array}$ & Terjadi Kesenjangan \\
\hline
\end{tabular}

Ditemukan pada aspek pembanding adanya kesenjangan antara kedua kondisi. Untuk kondisi-kondisi yang terjadi kesenjangan, maka akan dilakukan identifikasi tindakan untuk mengakomodasi kesenjangan antara kedua pihak yaitu pihak manajemen dan pihak customer.

\subsection{Identifikasi Tindakan}

Identifikasi tindakan merupakan tahapan mengidentifikasi keadaan terhadap perbedaan antara pihak manajemen dan customer dengan melakukan akomodasi terhadap perbedaan tersebut. Akomodasi adalah suatu keadaan di mana suatu konflik untuk mendapat penyelesaian, sehingga terjalin kerja sama yang baik kembali. Sehingga dimaksudkan dengan melakukan akomodasi dimana orang atau kelompok manusia yang mulanya saling bertentangan, dapat melakukan penyesuaian diri untuk mengatasi perbedaan tersebut. Proses akomodasi memiliki berapa bentuk yang terdiri dari:

1) Coercion yaitu yang dilaksanakan karena adanya paksaan.

2) Compromise yaitu dimana pihak-pihak mengurangi/mengalah.

3) Arbitration, yaitu suatu cara untuk mencapai compromise.

4) Conciliation, yaitu usaha untuk mempertemukan keinginan-keinginan.

5) Toleration, yaitu persetujuan.

6) Stalemate, dimana pihak memiliki kekuatan seimbang sehingga perselisihan berhenti pada satu titik tertentu.

7) Adjudication, penyelesaian konflik melalui jalur pengadilan.

Hasil identifikasi terhadap kesenjangan dapat dilihat pada tabel 2 . 
Tabel 2. Hasil Identifikasi Kesenjangan

\begin{tabular}{|c|c|c|}
\hline Aspek & $\begin{array}{c}\text { Kode } \\
\text { Kesenjangan } \\
\end{array}$ & Tindakan \\
\hline \multirow{3}{*}{ Bentuk SOP } & P011 & $\begin{array}{c}\text { Tidak dibutuhkan } \\
\text { tindakan }\end{array}$ \\
\hline & P012 & $\begin{array}{c}\text { Tidak dibutuhkan } \\
\text { tindakan }\end{array}$ \\
\hline & P013 & $\begin{array}{c}\text { Tidak dibutuhkan } \\
\text { tindakan }\end{array}$ \\
\hline \multirow{3}{*}{$\begin{array}{l}\text { Penulisan pada } \\
\text { Alur Proses }\end{array}$} & P021 & $\begin{array}{l}\text { Tidak dibutuhkan } \\
\text { tindakan }\end{array}$ \\
\hline & P022 & Akomodasi: Conciliation \\
\hline & P023 & Akomodasi: Compromise \\
\hline \multirow{2}{*}{ Visualisasi Alur } & P031 & $\begin{array}{c}\text { Tidak dibutuhkan } \\
\text { tindakan }\end{array}$ \\
\hline & P032 & $\begin{array}{c}\text { Tidak dibutuhkan } \\
\text { tindakan }\end{array}$ \\
\hline \multirow{3}{*}{ Isi SOP } & P041 & $\begin{array}{l}\text { Tidak dibutuhkan } \\
\text { tindakan }\end{array}$ \\
\hline & P042 & $\begin{array}{l}\text { Tidak dibutuhkan } \\
\text { tindakan }\end{array}$ \\
\hline & P043 & Akomodasi: Compromise \\
\hline $\begin{array}{l}\text { Formatting } \\
\text { Dokumen }\end{array}$ & P051 & $\begin{array}{c}\text { Tidak dibutuhkan } \\
\text { tindakan }\end{array}$ \\
\hline \multirow{3}{*}{$\begin{array}{l}\text { Tingkat Ke } \\
\text { rincian }\end{array}$} & P061 & $\begin{array}{c}\text { Tidak dibutuhkan } \\
\text { tindakan }\end{array}$ \\
\hline & P062 & $\begin{array}{c}\text { Tidak dibutuhkan } \\
\text { tindakan }\end{array}$ \\
\hline & P063 & Akomodasi: Compromise \\
\hline
\end{tabular}

\subsection{Identifikasi Perubahan}

Identifikasi perubahan dibutuhkan apabila pada suatu organisasi ingin melakukan perubahan menjadi lebih baik dari kondisi pada saat ini. Perubahan dilakukan agar kinerja suatu organisasi dapat menjadi lebih baik dari kondisi sebelumnya. Perubahan dapat diketahui berdasarkan kondisi saat ini dibandingkan dengan kondisi yang ingin diharapkan sehingga dari situlah di dapatkan kesenjangan antara kondisi keduanya. Kesenjangan inilah yang akan menjadi acuan untuk mengetahui perubahan apa saja yang akan dilakukan oleh suatu organisasi untuk menuju kondisi yang ingin diharapkan. Hal ini diketahui dengan melihat SOP layanan yang akan diubah berdasarkan kesenjangan antara kondisi persepsi manajemen dibandingkan kondisi harapan customer. Identifikasi perubahan pada penelitian ini dilakukan dengan melihat dari beberapa aspek, antara lain bentuk SOP, penulisan di dalam alur proses, visualisasi alur, isi SOP, formatting dokumen SOP, dan tingkat ke rincian.

\subsection{Identifikasi Dampak}

Dampak merupakan hal yang muncul dari adanya perubahan yang dilakukan oleh suatu organisasi. Begitu juga dengan kondisi existing terkait penanganan layanan domain dan hosting yang dilakukan perubahan menjadi bentuk SOP kondisi ideal menurut hasil analisis kesenjangan antara persepsi manajemen dan harapan customer, maka dapat menimbulkan suatu dampak yang terjadi.

\subsection{Identifikasi Recommendations}

Identifikasi solusi diperoleh berdasarkan identifikasi perubahan dan dampak yang telah dilakukan, dari dampak yang ditimbulkan maka dibuatlah solusi yang dapat menangani dampak. Identifikasi solusi digunakan untuk memberikan solusi seperti apa yang dapat dilakukan untuk mengatasi dampak yang terjadi. Solusi yang diberikan mengacu kepada proses analisis kesenjangan yang telah di analisis. Solusi yang diberikan dapat mempengaruhi aktivitas bisnis organisasi, baik dalam menambah atau mengurangi terhadap isi dari dokumen SOP yang ada. Solusi yang ditawarkan mengacu kepada Berikut harapan customer sebagai pengguna layanan. Beberapa poin perubahan terhadap dokumen SOP Layanan Domain dan Hosting ditunjukkan pada tabel 3 .

Tabel 3. Poin Perubahan Dokumen SOP

\begin{tabular}{|c|c|c|}
\hline Aspek & $\begin{array}{c}\text { Kode } \\
\text { Kesenjangan }\end{array}$ & Solusi yang dihasilkan \\
\hline \multirow{3}{*}{$\begin{array}{l}\text { Bentuk } \\
\text { SOP }\end{array}$} & P011 & $\begin{array}{l}\text { Membuat } 2 \text { Jenis SOP untuk } \\
\text { customer internal dan customer } \\
\text { eksternal }\end{array}$ \\
\hline & P012 & $\begin{array}{l}\text { Membedakan hasil bentuk SOP. } \\
\text { Untuk Internal berupa dokumen } \\
\text { dalam format .pdf dan untuk } \\
\text { Eksternal berupa SOP yang } \\
\text { akan di publish di website }\end{array}$ \\
\hline & P013 & $\begin{array}{l}\text { SOP yang dibuat akan menarik } \\
\text { dan mudah dipahami }\end{array}$ \\
\hline \multirow{3}{*}{$\begin{array}{l}\text { Penulisan } \\
\text { pada Alur } \\
\text { Proses }\end{array}$} & P021 & $\begin{array}{l}\text { Penyederhanaan terhadap } \\
\text { bentuk flowchart pada SOP } \\
\text { sebelumnya, yaitu kolom } \\
\text { pelaksana dan kolom aktivitas } \\
\text { dilakukan penggabungan. }\end{array}$ \\
\hline & P022 & $\begin{array}{l}\text { Penulisan dalam proses sesuai } \\
\text { kaidah SPOK }\end{array}$ \\
\hline & P023 & $\begin{array}{l}\text { Penulisan terhadap segala } \\
\text { muatan di dalam alur proses } \\
\text { dipastikan harus konsisten }\end{array}$ \\
\hline \multirow{2}{*}{$\begin{array}{l}\text { Visualisasi } \\
\text { Alur }\end{array}$} & P031 & $\begin{array}{l}\text { Bentuk visual alur proses dibuat } \\
\text { kedalam bentuk flowchart yang } \\
\text { sederhana }\end{array}$ \\
\hline & P032 & $\begin{array}{l}\text { Bentuk visual alur proses } \\
\text { menarik dan sederhana. }\end{array}$ \\
\hline \multirow{3}{*}{ Isi SOP } & P041 & $\begin{array}{l}\text { Dokumen SOP akan dibuat } \\
\text { lebih ringkas dan tidak terlalu } \\
\text { banyak isi }\end{array}$ \\
\hline & P042 & $\begin{array}{l}\text { Menghilangkan definisi-definisi } \\
\text { yang sudah diketahui orang } \\
\text { umum. }\end{array}$ \\
\hline & P043 & $\begin{array}{l}\text { Informasi penting yang harus } \\
\text { ada alur proses, syarat dan } \\
\text { ketentuan, serta formulir }\end{array}$ \\
\hline $\begin{array}{l}\text { Formatting } \\
\text { Dokumen }\end{array}$ & P051 & $\begin{array}{l}\text { Tampilan dokumen dibuat } \\
\text { menarik, rapi, dan mudah } \\
\text { dipahami }\end{array}$ \\
\hline \multirow[b]{2}{*}{$\begin{array}{l}\text { Tingkat } \\
\text { Ke rincian }\end{array}$} & P061 & $\begin{array}{l}\text { SOP tidak harus menjawab } \\
\text { semua pertanyaan }\end{array}$ \\
\hline & P062 & $\begin{array}{l}\text { SOP yang dibutuhkan untuk } \\
\text { customer eksternal tidak perlu } \\
\text { rinci }\end{array}$ \\
\hline
\end{tabular}




\begin{tabular}{|l|l|l|}
\hline & $\mathbf{P 0 6 3}$ & $\begin{array}{l}\text { Menghilangkan informasi- } \\
\text { informasi tidak penting }\end{array}$ \\
\hline
\end{tabular}

\subsection{Pembuatan SOP}

Hasil dokumen SOP Layanan Domain dan Hosting terdiri dari 2 bentuk yaitu dokumen SOP untuk customer internal dan bentuk SOP untuk customer internal. Bentuk SOP customer internal yaitu berupa dokumen SOP Layanan Domain dan Hosting yang mengacu pada hasil dari analisis kesenjangan dan Permenpan 2012. Berikut adalah unsur dokumentasi:

1. Halaman Judul (Cover). Halaman ini merupakan halaman pertama dari dokumen SOP yang bertujuan sebagai halaman identitas dokumen SOP. Pada halaman ini mencantumkan komponen informasi yang terdiri dari judul, identitas instansi dan logo, tahun pembuatan, serta gambar sebagai pendukung.

2. Halaman Pengesahan. Halaman pengesahan perlu dimasukan karena dokumen SOP ini merupakan pedoman setiap pegawai (baik pejabat struktural, fungsional, atau yang ditunjuk untuk melaksanakan satu tugas dan tanggung jawab tertentu) sehingga dokumen ini harus memiliki kekuatan hukum. Di halaman pengesahan ini juga terdapat informasi lain yang perlu ada atau dimasukkan yaitu diantaranya deskripsi singkat mengenai dokumen SOP, kolom revisi sebagai riwayat apabila terdapat perbaikan, dan copyright dokumen.

3. Daftar Isi. Merupakan unsur utama yang harus ada di dalam sebuah dokumen. Pada umumnya, karena prosedur-prosedur yang di SOP akan mencakup prosedur dan beberapa informasi penting terkait sehingga mengakibatkan dokumen SOP ini sangat tebal. Oleh karena itu, dokumen ini dapat dibagi ke dalam beberapa bagian, yang masing-masing memiliki daftar isi. Daftar isi digunakan di dalam SOP Layanan Domain dan Hosting untuk membantu mempercepat pencarian informasi.

4. Penjelasan Singkat Penggunaan. Sebagai sebuah dokumen yang menjadi manual, maka dokumen SOP Layanan Domain dan Hosting harus memuat informasi-informasi penting yang dibutuhkan oleh pengguna layanan. Informasi yang dimuat pada bab ini berisi tentang peraturan layanan. Selain itu juga dijelaskan terkait komponen-komponen prosedur, termasuk simbol-simbol di dalam flowchart sebagai keterangan informasi agar memudahkan pengguna dalam memahami alur aktivitas. Berikutnya adalah unsur dari bentuk prosedurnya:

1) Bagian Identitas. Bagian Identitas dari unsur prosedur dalam SOP dapat dijelaskan yaitu, Nomor SOP, Judul SOP, Deskripsi Layanan, Spesifikasi Layanan, Keterkaitan, Peralatan dan Perlengkapan dan Pencatatan dan Pendataan

2) Bagian Flowchart. Merupakan uraian mengenai langkah-langkah (prosedur) kegiatan beserta mutu baku dan keterangan yang diperlukan. Bagian flowchart ini berupa flowchart yang menjelaskan langkah-langkah kegiatan secara berurutan dan sistematis dari prosedur yang distandarkan, yang berisi: nomor kegiatan, uraian kegiatan yang berisi langkah-langkah (prosedur), pelaksana yang merupakan pelaku (aktor) kegiatan, mutu baku yang berisi kelengkapan, waktu, output dan keterangan. Agar SOP ini terkait dengan kinerja, maka setiap aktivitas hendaknya mengidentifikasikan mutu baku tertentu, seperti: waktu yang diperlukan untuk menyelesaikan persyaratan yang diperlukan (standar input) dan output. Mutu baku ini akan menjadi alat kendali mutu sehingga produk akhirnya dari sebuah proses benar-benar memenuhi kualitas yang diharapkan, sebagaimana ditetapkan dalam standar pelayanan.

Selain itu untuk bentuk SOP customer eksternal memiliki kode LTSI-E*(nomor SOP)*. Berdasarkan hasil analisis kesenjangan yang telah dilakukan bentuk SOP untuk customer eksternal dibuat lebih menarik. Penggunaan simbol dalam bentuk gambar dan penggunaan warna-warna dilakukan agar SOP yang dihasilkan dapat menyesuaikan dengan apa yang diharapkan oleh customer eksternal. Selain dalam bentuk visualisasi SOP, bentuk SOP customer eksternal juga memiliki informasi yang lebih sedikit. Customer eksternal hanya membutuhkan informasi apa yang menjadi kebutuhan customer dalam memperoleh layanan

\subsection{Verifikasi}

Selanjutnya akan dilakukan proses pengujian. Proses pengujian dibagi menjadi 2 yaitu tahap verifikasi dan tahap validasi. Tahap yang pertama yaitu tahap verifikasi. Verifikasi adalah sebuah aktivitas mengecek dokumen SOP yang telah dibuat berdasarkan analisis kesenjangan antara harapan customer dan persepsi manajemen. Tujuan dari tahap verifikasi ini adalah memastikan bahwa SOP yang telah dibuat sudah benar dan sesuai sehingga dapat diterapkan oleh LTSI sebagai pedoman yang terstruktur dalam memberikan layanan yang baik. Tahap verifikasi dilakukan kepada customer internal, yaitu Rizki selaku staf operasional LTSI. Berdasarkan hasil verifikasi, terdapat beberapa perbaikan pada dokumen SOP sebagai berikut:

1. Penambahan ketentuan pada penyediaan backup yang disediakan oleh DPTSI.

2. Penambahan ketentuan template website dari tim website ITS yang dapat digunakan oleh unit dan department.

3. Perubahan pada kapasitas penyimpanan server.

4. Penambahan ketentuan subfolder arek, elib, sites, dan riset.

5. Perubahan pada nama PIC menjadi PIC Domain dan Hosting.

6. Penambahan alur pada pembuatan SOP Layanan Domain dan VPS. 


\subsection{Validasi}

Setelah melewati tahap verifikasi, didapatkan hasil bahwa validasi dokumen SOP Layanan Domain dan Hosting dilakukan dengan cara pembuatan skenario dan checklist yang harus dilakukan. Hal ini dilakukan untuk mengetahui kesesuaian dokumen SOP tepat jika nantinya SOP ini diimplementasikan.

Terdapat 2 bentuk SOP yang akan dilakukan tahap uji validasi, yaitu SOP untuk customer internal dan SOP untuk customer eksternal. Untuk bentuk SOP customer internal validasi dilakukan dengan 3 responden, yaitu Wiwin, Edo serta Rizki selaku staf SLTSI. Sedangkan untuk bentuk SOP customer eksternal validasi dilakukan kepada Kemal selaku pengurus organisasi mahasiswa yang berkaitan langsung dengan layanan domain dan hosting.

\section{KESIMPULAN}

Hasil analisis kesenjangan pada penelitian ini menunjukkan bahwa SOP yang ada tidak dapat digunakan sebagai panduan dalam operasional layanan karena DPTSI sebagai penyedia layanan tidak tepat dalam memahami apa yang diinginkan atau dibutuhkan customer

Berdasarkan hasil analisis kesenjangan yang dilakukan, maka terdapat 5 perubahan prosedur lama yang dilakukan, terdiri dari prosedur yaitu, SOP pembuatan layanan domain, Web Hosting, dan VPS yang terdiri dari 2 prosedur yaitu Prosedur Pembuatan Domain dan Web Hosting dan prosedur pembuatan domain dan VPS, SOP penitipan dan pengambilan server yang terdiri dari 2 prosedur yaitu prosedur penitipan server dan prosedur pengambilan server, SOP Pembaruan Data Contact Person, SOP Perpanjangan dan Penghentian Kontrak yang terdiri dari prosedur Perpanjangan dan Penghentian Kontrak, dan prosedur dan formulir dibukukan secara terpisah menjadi sebuah dokumen produk dengan judul Dokumen Standard Operating Procedure (SOP) Layanan Domain dan Hosting LTSI ITS.

Pengujian dokumen SOP dilakukan dengan cara verifikasi dan validasi. Pada verifikasi dilakukan wawancara dengan pihak operasional Subdit LTSI sebagai customer internal. Dari verifikasi yang telah dilakukan, terdapat beberapa perubahan yang dilakukan seperti disebutkan sebelumnya. Sedangkan pada tahap validasi, dilakukan 2 kali dengan menggunakan skenario yang sama namun dengan orang dan SOP yang berbeda. Pengujian validasi dokumen SOP yang pertama dilakukan kepada customer internal yaitu staf operator LTSI. Dan yang kedua dilakukan pengujian validasi SOP kepada pengurus Organisasi Mahasiswa.

Berdasarkan hasil validasi yang telah dilakukan, dengan menggunakan 4 skenario didapatkan hasil bahwa, pengguna dapat memahami cara kerja dan penggunaan dokumen SOP, pengguna dapat membaca alur yang terdapat dalam dokumen SOP, pengguna dapat melakukan instruksi yang terdapat dalam dokumen SOP, pengguna dapat melakukan pencatatan atau pengisian pada formulir terkait, sesuai instruksi pada dokumen SOP.

\section{SARAN}

Berdasarkan penelitian yang dilakukan, didapati bahwasanya terdapat turunan dari SOP yang dapat dibuat untuk melengkapi SOP layanan TI di studi kasus. Turunan SOP tersebut dapat dibentuk dalam instruksi kerja, checklist pengendalian kualitas serta bentuk turunan yang lain. Penelitian berikutnya dapat difokuskan pada penggalian turunan SOP ini sehingga tata kelola TI terkait Layanan Domain dan Hosting bisa lebih lengkap dan komprehensif.

Selain itu, dengan metode yang sama yang dilakukan di penelitian ini, ke depannya dapat juga dibuat SOP layanan yang lain sehingga studi kasus mampu memiliki dokumen tata kelola TI yang lengkap.

\section{DAFTAR PUSTAKA}

Ali, A. H. N., dkk. 2013 'Evaluasi Kinerja Aplikasi Indeks Pengajaran Dosen Dengan Menggunakan Gap Analysis', J. Tek. POMITS.

Herdiyanti, A., Puspitaningrum, A. C., Astuti, H. M., \& Yuhana, U. L. 2018. Pembuatan standard operating procedure pengembangan sistem informasi manajemen: studi kasus DPTSI ITS. SISFO VOL 8 NO $1,8$.

Rachmi, A., Susanto, T. D., dan Herdiyanti, A. 2014. 'Pembuatan Standard Operating Procedure (SOP) Service Desk Berdasarkan Kerangka Kerja Itil V3 dengan Menggunakan Metode Analisis Gap Layanan (Studi Kasus: PT. XYZ, Tangerang)', J. Tek. ITS, vol. 3, no. 2, pp. A175-A180.

Albrecht, B., \& Pirani, J. A. 2004. 'Using an IT Governance Structure to Achieve Alignment at the University of Cincinnati', Educ. Cent. Appl. Res.

Hermana, B. 2015. 'Teknik Analisis Masalah: Gap Analysis dan SWOT Analysis'. [Online]. Available: https://id.scribd.com/document/396940694/Analisis -Gap. [Accessed: 22-Mar-2019].

Boundless, 'The GAP Model'. [Online]. Available: boundless.com. [Accessed: 22-Mar-2019].

Henderi dan Sunarya, A. 2008. 'Peranan IT Governance Dalam Meningkatkan Kinerja Organisasi ':, vol. 2, no. 40 , pp. 1-12.

Akyar, I. 2012. 'Standard Operating Procedures (What Are They Good For?)'.

Bianchi, I. S., dan Sousa, R. D. 2016. 'IT Governance Mechanisms in Higher Education', Procedia Comput. Sci., vol. 100, pp. 941-946.

Sudibyo, L. 2011. 'Peranan dan Dampak Teknologi Informasi dalam Dunia Pendidikan di Indonesia', J. WIDYATAMA Univ. Veteran Bangun Nusantara. Sukoharjo, vol. 20, pp. 175-185. 
De Haes, S., dan Van Grembergen, W. 2015. Enterprise Governance of Information Technology, Management for Professionals.

Greene, S. S. 2014. Security Program and Policies: Principles and Practices. Pearson IT Certification.

Armoko, T. 2012. 'Standar Operasional Prosedur (SOP) dan Akuntabilitas Kinerja Instansi Pemerintah'.

Susanto, T. D. 2016. Manajemen Layanan Teknologi Informasi. AISINDO.

\section{UCAPAN TERIMA KASIH}

Penelitian ini merupakan penelitian yang di danai oleh Institut Teknologi Sepuluh Nopember dengan skema Penelitian Kebijakan 2019. Kami berterima kasih kepada Lembaga Penelitian dan Pengabdian Masyarakat, Institut Teknologi Sepuluh Nopember atas kesempatan yang diberikan. Semoga penelitian ini membawa kemanfaatan untuk Institut Teknologi Sepuluh Nopember. 